\title{
44. PEBBLES AND CARBONATE NODULES FROM DEEP SEA DRILLING PROJECT LEG 56 CORES
}

\author{
Hakuyu Okada, Geoscience Institute, Faculty of Science, Shizuoka University, Shizuoka, Japan
}

\begin{abstract}
At all DSDP Leg 56 drilling sites, exotic pebbles occur commonly, throughout the cores. Chips of carbonate nodules occur only at Site 434 on the lower inner trench wall. Both exotic pebbles and carbonate nodule chips sometimes tend to be concentrated at particular levels of cores.

Exotic pebbles are generally well rounded and consist of various rock types, such as dacite, andesite, basalt, tuff, gabbro, granodiorite, metaquartzite, biotite hornfels, lithic wacke, mudstone, etc., of which dacite occurs commonly at all the sites. Almost all pebbles at Site 436 and most at Sites 434 and 435 may have been rafted by ice. Some at the latter sites may have been derived by down-slope slumping.

Carbonate nodules consist of microcrystalline dolomite, manganoan calcite, and siderite; $\mathrm{CaCO}_{3}$ content ranges from 22 to 65 per cent. They are also generally characterized by a high content of $\mathrm{P}_{2} \mathrm{O}_{5}$. The nodules are commonly rich in diatom remains, some of which indicate that the nodules are autochthonous. Some nodules contain abundant glass shards, with a modal refractive index of 1.499 , almost identical to shards in the surrounding mud and ooze. These facts suggest that the carbonate nodules may have been formed diagenetically, in situ. This may throw light on problems of the formation of carbonate nodules in ancient "geosynclinal" sediments. It is also very important to point out that these carbonate nodules were formed within sediment deposited well below the CCD.
\end{abstract}

\section{INTRODUCTION}

A large number of exotic pebbles and chips of carbonate nodules were collected from many cores recovered at DSDP Leg 56 sites of the Japan Trench transect (Figure 1), although we found actual carbonate nodules only at Site 434 . These pebbles and carbonate nodules are important to clarify depositional environments of sediments: paleogeography, tectonism, transportation mechanism, glaciation, diagenesis, and so on.

This paper describes the occurrence and petrography of these pebbles and nodules and discusses their origin.

\section{OCCURRENCE}

Figure 2 shows occurrences of exotic pebbles and chips of carbonate nodules in the cores from Sites 434 , 435 , and 436 . These pebbles and nodules generally occur as isolated pieces in mud and mudstone (Figures 3, 4A), and are sometimes clustered (Figure 4B). Occasional concentrations of pebbles and nodule chips at the tops of cores may have been induced artificially by drilling.

\section{Site 434}

Both exotic pebbles and nodule chips are scattered throughout Holes 434, 434A, and 434B. Stratigraphic positions at which they occur range from upper Pliocene

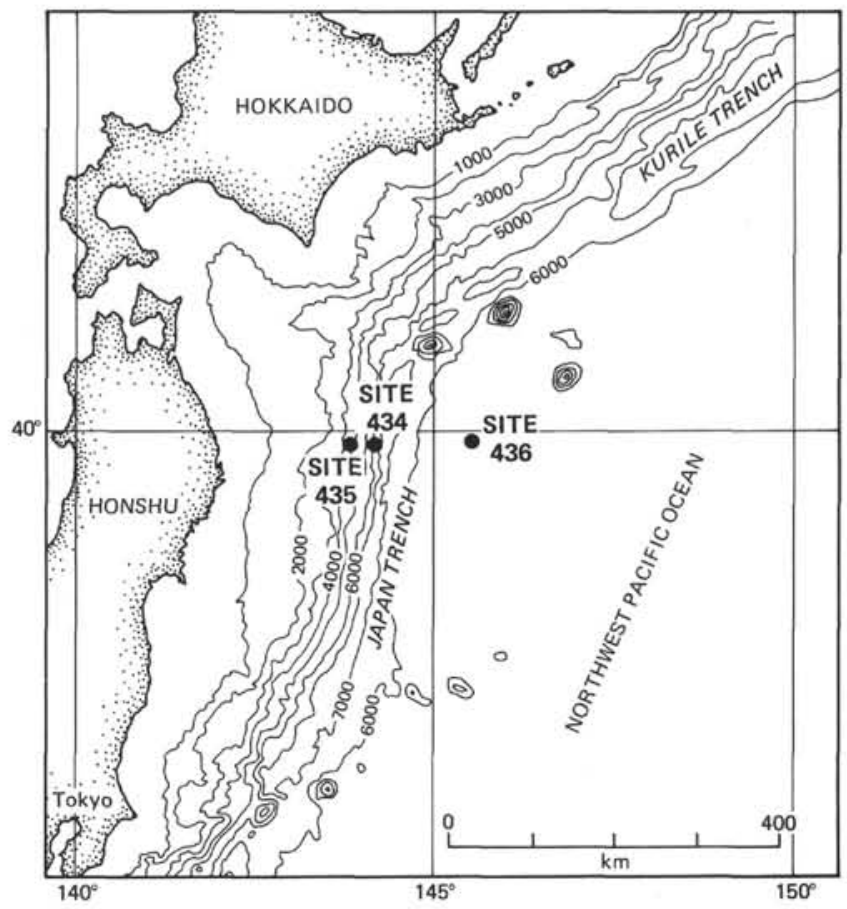

Figure 1. Locations of DSDP Leg 56 drill sites. Bathymetry in meters. 

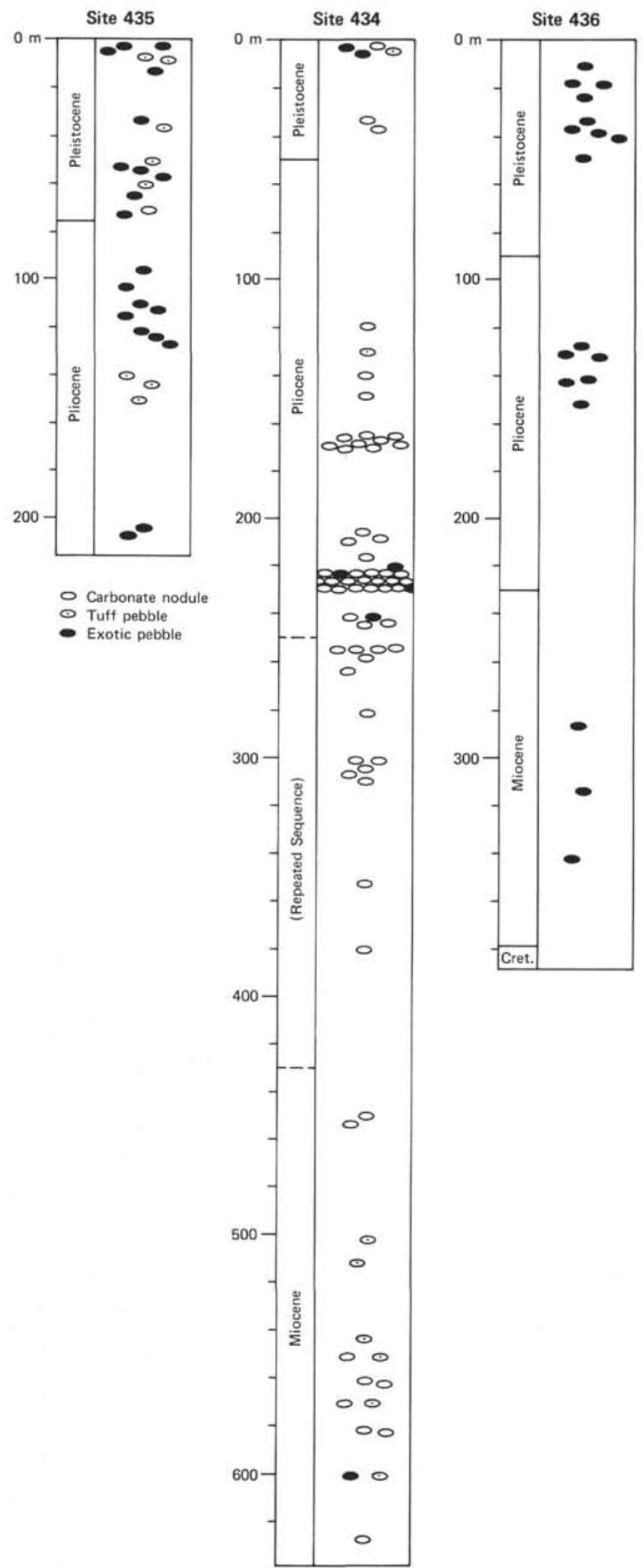

Figure 2. Distribution of exotic pebbles and chips of carbonate nodules in cores from Sites 434, 435, and 436. to upper Miocene. Nodule chips are far more abundant than exotic pebbles. Many exotic pebbles are well rounded. Large chips of the carbonate nodules (Figures 5 and 6) are definitely cored-through pieces of originally much larger rock bodies. It is also interesting that a few cored pieces of carbonate nodules occur in the form of breccias (Figure 6). In Section 434-25-2, more than 25 pieces of carbonate nodules are concentrated at the interval between 82 and $96 \mathrm{~cm}$ (Figure 4B), although a few exotic pebbles are admixed with them.

\section{Site $\mathbf{4 3 5}$}

Exotic pebbles of various kinds of rocks are scattered throughout the holes (Table 1, Figure 2). Many pebbles are more or less rounded (Figure 7). We found only two pieces of carbonate nodules, which were restricted to the interval 435-9-1, 124-126 cm.

\section{Site $\mathbf{4 3 6}$}

We collected considerably rounded exotic pebbles, which occurred sporadically in Cores 2 to 6 (Pleistocene), 14 to 17 (Pliocene), and 31, 34, and 37 (Miocene). Pebbles are much less common in the Pliocene and Miocene sequences than in the Pleistocene. No carbonate nodules were found.

\section{PETROGRAPHY}

\section{Procedures}

Sixty-nine samples were collected for petrographic study. Qualitative and semiquantitative thin-section analyses were made on all samples. Some carbonate samples were selected for further studies (X-ray diffraction, chemical analysis, and diatom analysis).

\section{Exotic Pebbles}

\section{Volcanic Rocks}

Pebbles of volcanic and related rocks include dacite, andesite, basalt, vitric tuff, tuff breccia, and scoria (Table 1). Among these, dacite and vitric tuff are the most common rock types.

Dacite pebbles are present at all the sites; they are more common at Sites 435 and 436. Dacite pebbles consist of augite-hypersthene dacite (Plate 1, Figures 1 and 2 ), hornblende-biotite-augite-hypersthene dacite (Plate 1, Figure 3), hornblende dacite, hornblende-biotite dacite, and intensely silicified dacite (Plate 1, Figure 4). Plagioclase phenocrysts are euhedral and range in size from 0.2 to $2.7 \mathrm{~mm}$. They are more or less altered to kaolinite or calcite, and sometimes wholly to sericite. Phenocrysts of hornblende, augite, and hypersthene are subhedral to euhedral, 0.3 to $1 \mathrm{~mm}$ long, and more or less replaced by at least one of epidote, chlorite, magnetite, and calcite. The groundmass, composed of oligoclase microlites $(<0.06 \mathrm{~mm})$, is generally hyalopilitic and more or less silicified.

Andesite pebbles were sampled at Sites 434 and 435. They include augite-hypersthene andesite (Plate 1, Fig- 

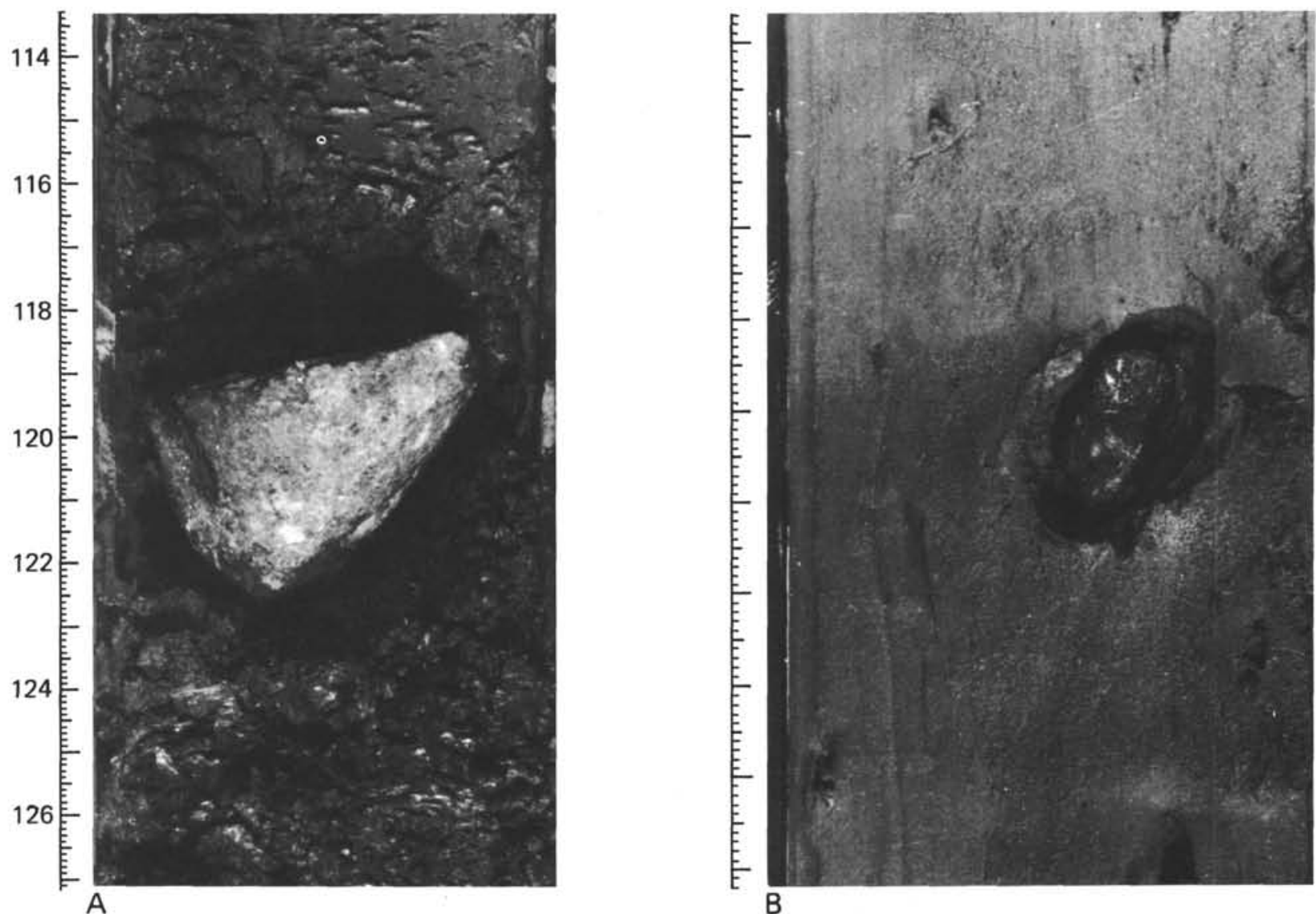

Figure 3. Isolated exotic pebbles. Scale in $\mathrm{mm}$. A. Chip of a rounded pebble of dacitic tuff in diatomaceous mudstone (Sample 434-15-1, 118-122 cm). B. Subrounded slate pebble in muddy diatom ooze (Sample $436-2-2,56-58 \mathrm{~cm}$ ).

ures 5,6), hornblende-augite andesite, and hypersthene andesite (Plate 1, Figures 7, 8). Plagioclase phenocrysts $(0.6-1.5 \mathrm{~mm} \times 1.3-2.4 \mathrm{~mm})$ are euhedral to subhedral, and some show zonal structures. The composition varies from andesine in Samples 434-25-2, 86-90 $\mathrm{cm}$ and 434-27-1, $65 \mathrm{~cm}$ to labradorite in Sample 435-7-1, 43-44 $\mathrm{cm}$. Plagioclase phenocrysts are mostly replaced by kaolinite and partly by epidote, and sometimes wholly by sericite, as in Sample 435A-8-1, 15-17 cm. Mafic phenocrysts $(0.3-1 \mathrm{~mm})$ are altered generally to chlorite and sometimes either to epidote or to calcite. The groundmass, composed of plagioclase laths $(0.2 \mathrm{~mm})$, shows hyalopilitic texture and is more or less silicified.

We found a basalt pebble only at Site 435 ; it is highly altered. Phenocrysts $(0.3 \mathrm{~mm})$ are euhedral plagioclase and augite, altered respectively to kaolinite and chlorite. The subvitreous groundmass is composed of plagioclase, augite, olivine, and chlorite.

Pebbles of tuff are mostly vitric tuff, with crystals of such minerals as plagioclase, augite, hornblende, and biotite. Many samples of tuffaceous pebbles are more or less calcareous. Abundant glass shards are cemented mostly by micrite, and occasionally by sparry calcite. Therefore, there are many gradations from tuff to marlstone. These tuffs are rhyolitic. In Sample 434B-3-1, $30-32 \mathrm{~cm}$, the index of refraction of glass shards varies from 1.497 to 1.500 . There is nothing to indicate welded texture in these tuffs.

Pebbles of tuff breccia occur at Site 434 . They are composed either of volcanic fragments such as basalt, dacite, and pumice (Sample 434-25-2, 86-90 cm; Plate 2 , Figure 1) or of vitric-tuff fragments (Samples 434B24-1, 87-90 cm; 434B-31,CC, 16-17 cm). These fragments are set in glass-rich calcareous cement. In addition, we collected a pebble of probably andesitic scoria with small amounts of augite and hypersthene microlites (Plate 2, Figure 7).

\section{Plutonic Rocks}

Well-rounded pebbles of augite gabbro and granodiorite occur at Sites 434 and 435 , respectively. The gabbro (Sample 434B-34-1, 6-8 cm; Plate 2, Figures 3, 4) shows ophitic texture and is composed of euhedral to subhedral plagioclase (larger crystals $1.8 \times 2.1 \mathrm{~mm}$; average $1 \mathrm{~mm}$ long) and subhedral to anhedral augite. The composition of plagioclase is $\mathrm{An}_{51}$. Augite is partly replaced by chlorite. Magnetite occurs as an accessory in close association with augite.

Granodiorite (Sample 435-14-1, 12-15 cm; Plate 2, Figure 2) has granular texture and comprises plagioclase, biotite, hornblende, and quartz. Plagioclase (about $1 \mathrm{~mm}$ long), is subhedral and its compotition is $\mathrm{An}_{43}$. 


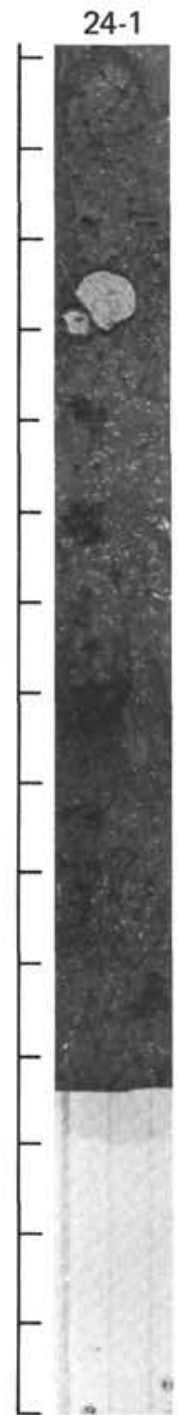

A
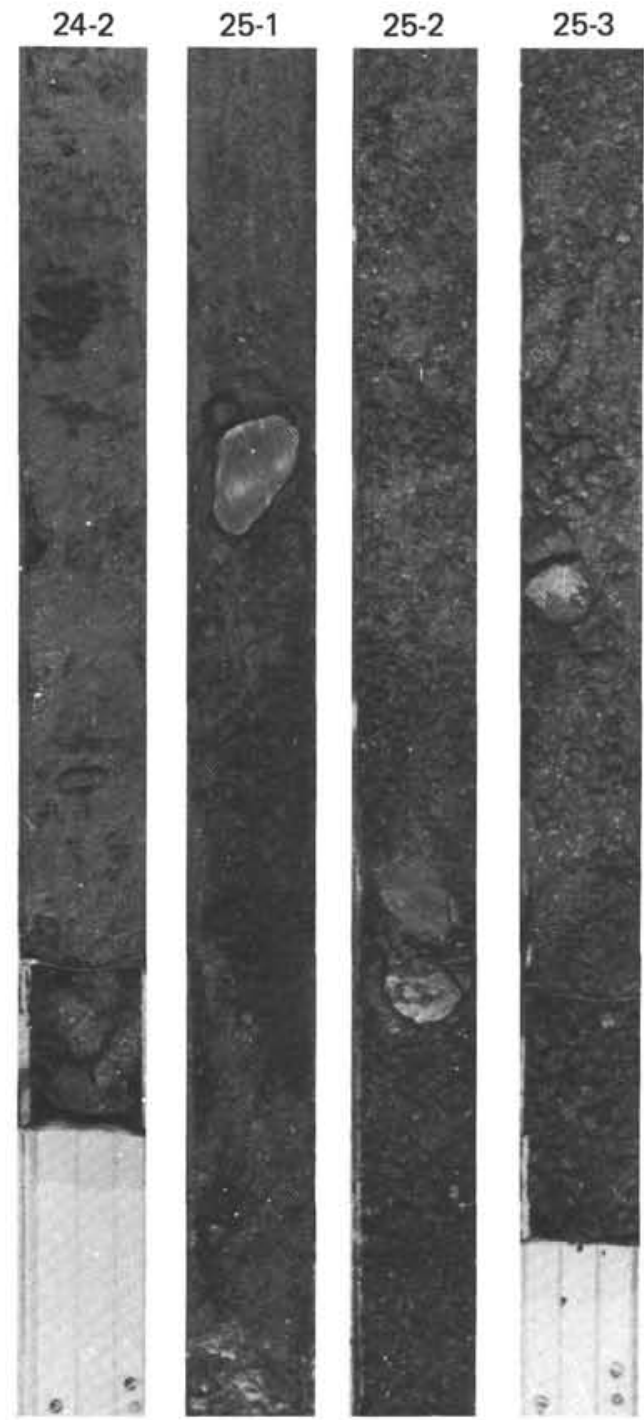

Figure 4. Occurrence of pieces of carbonate nodules. Scale in $\mathrm{cm}$. A. Isolated chips of carbonate nodules in tuffite from Hole 434B. B. About 25 pieces of carbonate nodules and a few exotic pebbles concentrated from 80 to $95 \mathrm{~cm}$ of Section 434-25-2.

\section{Metamorphic Rocks}

Pumpellyite metaquartzite and biotite hornfels were collected from Site 435 and Site 436, respectively. The former consists exclusively of pumpellyite and quartz in almost equal amounts (Plate 2, Figures 5, 6). Pumpellyite occurs as irregular patches and fillings along sutures of mylonitized quartz crystals. It is yellow, without distinct pleochroism and shows anomalous interference colors of bluish gray to yellowish gray. Quartz is polycrystalline and consists of elongate grains with intense undulatory extinction.

Biotite hornfels (Sample 436-4-4, 60-66 cm; Plate 2, Figure 8 ) was originally poorly sorted, very fine-grained, quartzose wacke. Much of the matrix is replaced by brownish biotite microlites and their aggregates.

\section{Sedimentary Rocks}

Pebbles of sandstone and mudstone are found occasionally at all the sites. They are considerably rounded.

Sandstone pebbles were collected from Sites 435 and 436. They consist of fine-grained lithic wacke. A modal analysis is shown in Table 2. In Sample 435-14-1, 4-7 $\mathrm{cm}$, quartz, feldspar, and lithic clasts are major detrital constituents; they are all subangular to angular. Quartz grains are almost exclusively monocrystalline, without inclusions, and are partly replaced along the margin by calcite. Plagioclase (andesine) is rather fresh. Lithic fragments are mostly dacitic rocks. There are also flakes of biotite and sericite, slightly bent around sand grains. The matrix consists of aggregates of chlorite and biotite. Accessories include epidote and iron ores. 
TABLE 1

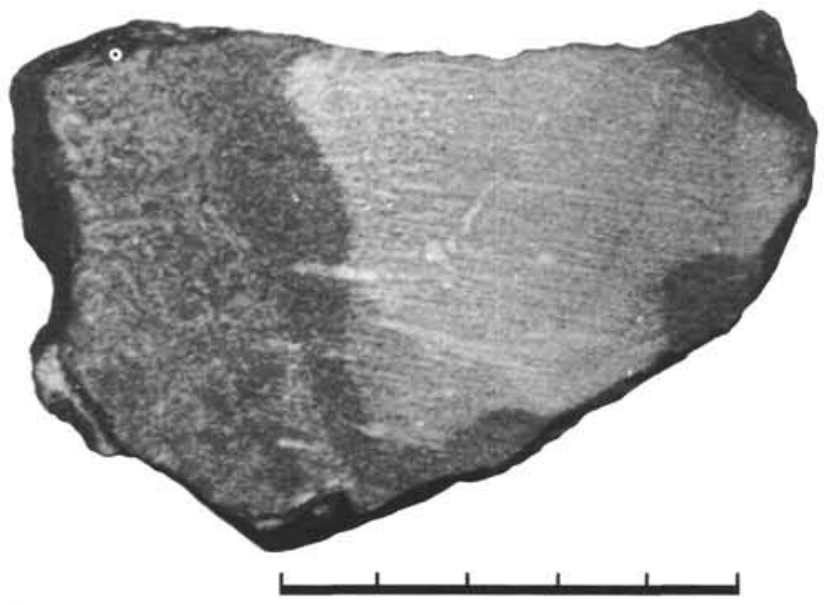

Figure 5. A piece of carbonate nodule probably drilled from an originally much larger rock body. Note scratches due to drilling. Sample 434-27-1, 62-70 cm. Scale in $\mathrm{cm}$.

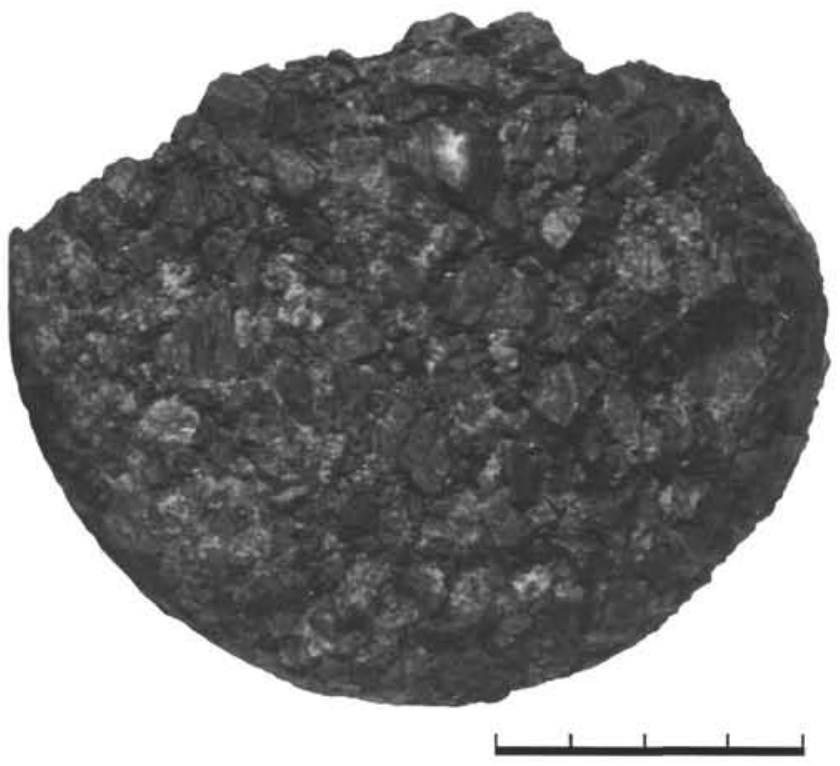

Figure 6. Marlstone breccia. Sample 434-28, CC. Scale in $\mathrm{cm}$.

Sample 435-14-1, 12-15 cm (Plate 3, Figure 1) is of poorly sorted, very fine-grained lithic wacke. Quartz is represented by angular, monocrystalline grains. Feldspar grains are usually replaced by kaolinite. Lithic clasts include slate, limestone, chert, dacite, and phyllitic rocks, of which slate is predominant. The matrix is composed almost entirely of mud, accompanied by small amounts of biotite and calcite.

Sample $436-2-2,37-38 \mathrm{~cm}$ is silicified, fine-grained lithic sandstone. The original matrix or cement of the sandstone is entirely replaced by silica. The rock itself is also characterized by a network of chalcedony veinlets. Quartz grains are mostly monocrystalline, and their original outlines are obscured by silicification. Feldspar is more or less altered to kaolinite or sericite. Lithic
Examined Pebbles and Nodules from Leg 56 Cores

\begin{tabular}{|c|c|}
\hline $\begin{array}{l}\text { Sample } \\
\text { (interval in } \mathrm{cm} \text { ) }\end{array}$ & Rock Name \\
\hline $4-15-1,120-124$ & $\begin{array}{l}\text { Devitrified, hornblende- and biotite-bearing } \\
\text { dacitic tuff }\end{array}$ \\
\hline $19-1$ & Glass-shard-bearing, diatom-rich marlstone \\
\hline $19-1,10-12$ & $\begin{array}{l}\text { Pyrite-bearing, diatom-rich marlstone, with } \\
\text { rare plagioclase }\end{array}$ \\
\hline $19, \mathrm{CC}$ & Plagioclase-bearing, vitric tuff \\
\hline $23-1,140-143$ & $\begin{array}{l}\text { Diatom-bearing marlstone with common glass } \\
\text { shards }\end{array}$ \\
\hline $23-3,49$ & $\begin{array}{l}\text { Diatomaceous micritic limestone with rare } \\
\text { plagioclase }\end{array}$ \\
\hline $25-2,86-90(1)$ & $\begin{array}{l}\text { Glass-shard-bearing, diatom-rich marlstone } \\
\text { with common plagioclase }\end{array}$ \\
\hline $25-2,86-90(2)$ & Altered hornblende-augite andesite \\
\hline $25-2,86-90(3)$ & Silicified biotite-hornblende dacite \\
\hline $25-2,86-90(4)$ & $\begin{array}{l}\text { Volcanic breccia composed of dacitic pumice, } \\
\text { andesite, and olivine basalt }\end{array}$ \\
\hline $25-2,86-90(5)$ & $\begin{array}{l}\text { Plagioclase-bearing marlstone with common } \\
\text { diatoms and glass shards }\end{array}$ \\
\hline $27-1,65(1)$ & Diatom- and glass-shard-rich marlstone \\
\hline $27-1,65(2)$ & Hypersthene-augite andesite \\
\hline $28, \mathrm{CC}$ & Sparite-cemented micrite \\
\hline $28-1,104-106$ & $\begin{array}{l}\text { Diatom-plagioclase-augite-pumice-bearing } \\
\text { marlstone with common glass shards }\end{array}$ \\
\hline $29, \mathrm{CC}, 12-14$ & $\begin{array}{l}\text { Glass-shard-rich marlstone with rare biotite, } \\
\text { augite, and hornblende, and common diatoms } \\
\text { and plagioclase }\end{array}$ \\
\hline $\begin{array}{r}34 \mathrm{~A}-1-2,24-25 \\
1-4,62-64\end{array}$ & $\begin{array}{l}\text { Plagioclase-bearing, tuffaceous mudstone } \\
\text { Augite- and plagioclase-bearing, biotite-rich tuff }\end{array}$ \\
\hline $34 \mathrm{~B}-3-1,30-32$ & $\begin{array}{l}\text { Diatom-, augite-, and biotite-bearing marlstone } \\
\text { with common plagioclase and glass shards }\end{array}$ \\
\hline $11, \mathrm{CC}, 2-6$ & $\begin{array}{l}\text { Marlstone with rare diatoms, and common } \\
\text { biotite, plagioclase, and glass shards }\end{array}$ \\
\hline $19-1,5-7$ & $\begin{array}{l}\text { Diatom-, and augite-bearing marlstone with } \\
\text { rare plagioclase and common glass shards }\end{array}$ \\
\hline $19-2,33-35$ & $\begin{array}{l}\text { Diatom-and augite-bearing, sandy marlstone } \\
\text { with rare plagioclase and common glass shards }\end{array}$ \\
\hline $24-1,87-90$ & Diatom-bearing, calcareous tuff breccia \\
\hline $25-1,97-104$ & $\begin{array}{l}\text { Zircon-bearing, calcareous vitric tuff with } \\
\text { common diatoms }\end{array}$ \\
\hline $28-1,115-117$ & Calcareous vitric tuff with common diatoms \\
\hline $29, \mathrm{CC}, 0-3$ & Calcareous vitric tuff \\
\hline $29, \mathrm{CC}, 6-8$ & $\begin{array}{l}\text { Diatom-bearing marlstone with common glass } \\
\text { shards }\end{array}$ \\
\hline $30-1,5-10$ & Plagioclase-bearing, glass-shard-rich marlstone \\
\hline $31, \mathrm{CC}, 8-10$ & Diatom- and glass-shard-rich marlstone \\
\hline $31, \mathrm{CC}, 16-17$ & Diatom-bearing, calcareous tuff breccia \\
\hline $32, \mathrm{CC}, 10-12$ & Diatom- and spicule-rich marlstone \\
\hline $32, \mathrm{CC}, 12-14$ & Diatom-rich marlstone \\
\hline $34-1,6-8$ & Augite gabbro \\
\hline $34-1,7-8$ & $\begin{array}{l}\text { Pumice-bearing, calcareous vitric tuff with } \\
\text { common diatoms }\end{array}$ \\
\hline $35-5-3,11-12$ & Augite-hypersthene dacite \\
\hline $5-4,40-42$ & Plagioclase-bearing vitric tuff \\
\hline $6-6,31-33$ & $\begin{array}{l}\text { Hornblende- and biotite-bearing vitric tuff } \\
\text { with common plagioclase }\end{array}$ \\
\hline $7-1,19-20$ & Augite-hypersthene dacite \\
\hline $7-1,43-44$ & Hypersthene andesite \\
\hline $7-1,106-107$ & Metabasalt \\
\hline $7-4,9-10$ & Andesitic tuff breccia \\
\hline $8-2,111-113$ & Silicified dacite \\
\hline $9-1,124-126$ & $\begin{array}{l}\text { Dacite-fragment-bearing, diatomaceous marl- } \\
\text { stone with rare augite and biotite and common } \\
\text { glass shards }\end{array}$ \\
\hline $9-1,126-128$ & $\begin{array}{l}\text { Diatomaceous marlstone with rare plagioclase } \\
\text { and common glass shards }\end{array}$ \\
\hline $10-1,45-46$ & Plagioclase-bearing pumice \\
\hline $11-3,32-33$ & $\begin{array}{l}\text { Biotite-bearing mudstone with common } \\
\text { limonite }\end{array}$ \\
\hline $14-1,4-7(1)$ & Pumpellyite metaquartzite \\
\hline $14-1,4-7(2)$ & Fine-grained lithic wacke \\
\hline $14-1,12-15(1)$ & Hornblende-biotite granodiorite \\
\hline
\end{tabular}


TABLE 1 - Continued

\begin{tabular}{cl}
\hline $\begin{array}{c}\text { Sample } \\
\text { (interval in cm) }\end{array}$ & \multicolumn{1}{c}{ Rock Name } \\
\hline $435-14-1,12-15(2)$ & Fine-grained lithic wacke \\
$16-1,12-15$ & Plagioclase-bearing vitric tuff with rare biotite \\
435 A-2-1, 1-3 & Plagioclase-bearing vitric tuff \\
$8-1,15-17$ & Altered, quartz-bearing hornblende-pyroxene \\
& andesite \\
$8-1,19-22$ & Silicified dacite \\
$436-2-2,37-38$ & Fine-grained lithic wacke with silica veinlets \\
$3-2,98-99$ & Vitric tuff \\
$3-4,6-9$ & Vitric tuff \\
$4-4,60-66$ & Biotite hornfels \\
$4-6,21-22$ & Vitric tuff \\
$14-2,29-30$ & Scoria \\
$15-1,8-10$ & Silicified dacite \\
$16-1,4-6$ & Andesitic tuff \\
$16-3,86-87$ & Altered dacite \\
$17-1,32-33$ & Silicified dacite \\
$27-1,37-39$ & Silicified hornblende dacite \\
$31-1,1-3$ & Hornblende-biotite-pyroxene dacite \\
$31-1,10-11$ & Intensely silicified volcanic rocks \\
$31-1,62-63$ & Vitric tuff \\
\hline
\end{tabular}

fragments consist chiefly of altered vitreous volcanics. Zircon, garnet, and chlorite are accessories, among which zircon is most common.

The compositions of these sandstone pebbles are clearly different from those of Upper Cretaceous sandstones from Hole 439, Leg 57 (Table 2), as shown by proportions of quartz (Q), feldspar (F), and lithic fragments (L):

Leg 56: Sample 435-14-1, 4-7 $\mathrm{cm}=\mathrm{Q}_{28} \mathrm{~F}_{35} \mathrm{~L}_{37}$ Sample 435-14-1, 12-15 $\mathrm{cm}=\mathrm{Q}_{30} \mathrm{~F}_{24} \mathrm{~L}_{46}$ Sample 436-2-2, 37-38 cm $=\mathrm{Q}_{17} \mathrm{~F}_{30} \mathrm{~L}_{53}$

Leg 57: Sample 439-30-5, 8-11 $\mathrm{cm}=\mathrm{Q}_{8} \mathrm{~F}_{6} \mathrm{~L}_{86}$ Sample 439-31-4, 51-53 cm $=\mathrm{Q}_{7} \mathrm{~F}_{4} \mathrm{~L}_{89}$

\section{Carbonate Nodules}

\section{Texture}

Most carbonate nodules are yellowish brown (10YR $5 / 4$ ) and show a homogeneous, microcrystalline texture. Diatom remains are embedded in the nodules, and sometimes plagioclase, quartz, and (or) glass shards are scattered throughout (Plate 3, Figures 2-6 and 8).
There are also some examples of carbonate breccias (Samples 434-28,CC; 434B-29,CC; Plate 3, Figure 7). These rocks show that sharp fragments of micritic carbonate rocks are cemented by coarsely crystalline sparite. These micritic fragments of various sizes occasionally contain diatom tests and glass shards.

\section{Composition}

As described above, carbonate minerals of the nodules show exclusively microcrystalline or cryptocrystalline texture. In almost all the samples, diatom tests are common to abundant, and in some samples such clasts as plagioclase, quartz, and glass float in the micro-crystalline carbonate matrix.

Powder X-ray-diffraction analysis of some selected samples shows that the carbonate minerals in most samples are dolomite and those in some are manganoan calcite accompanied by siderite (Figure 8 ). The (100) peak of $29.8^{\circ}$ identified as that of manganoan calcite in Figure 8 seems to indicate a shift of the $29.4^{\circ}$ peak of calcite caused by the addition of $\mathrm{Mn}$, but not affected by $\mathrm{Mg}$, as the chemical composition of the rock shows (Table 3 , analyses 5 and 6).

The chemical composition of seven samples is given in Table 3. The $\mathrm{CaCO}_{3}$ content is unexpectedly rather low, ranging from 22 to 65 per cent; this suggests that many nodule samples can be classified as marlstone, and some either as calcareous vitric tuff or as micritic limestone.

The contents of $\mathrm{SiO}_{2}$ and $\mathrm{Al}_{2} \mathrm{O}_{3}$ are not as high as in carbonate nodules from Tertiary strata in the Joban and Oga areas in northern Honshu (Hirabayashi, 1977). Some samples (434B-30-1, 5-10 cm; 434B-32, CC, 12 $14 \mathrm{~cm}$ ) show an extraordinarily high content of $\mathrm{MnO}$. This is in harmony with the existence of manganoan calcite (Figure 8). It is also noted that the nodules from Leg 56 cores have in general a high content of $\mathrm{P}_{2} \mathrm{O}_{5}$. Ironrich materials represented by Sample 434B-32, CC, 12 $14 \mathrm{~cm}$ are characterized by siderite (Figure 8 ).

\section{Paleontology}

Fossil planktonic diatoms, which are abundant at Sites 434 and 435 as well as in the upper section of Site 436 , are common to abundant in carbonate nodules.
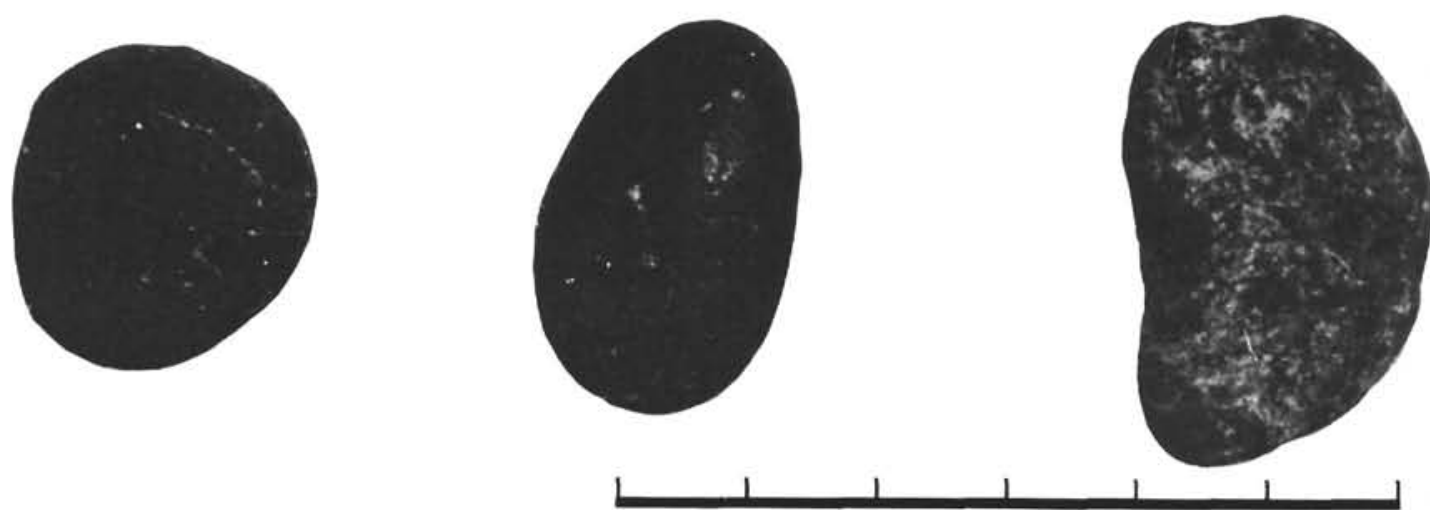

Figure 7. Examples of well-rounded pebbles. All came from the interval 435-14-1, 4-7 cm. 
TABLE 2

Modal Analyses of Sandstone Pebbles Collected from Leg 56 Cores and Sandstones Drilled at Leg 57 Sites

\begin{tabular}{lccccc}
\hline & \multicolumn{5}{c}{ Samples } \\
& $435-14-1$, & $435-14-1$, & $436-2-2$, & $439-30-5$, & $439-31-4$, \\
Component & $4-7 \mathrm{~cm}$ & $12-15 \mathrm{~cm}$ & $37-38 \mathrm{~cm}$ & $8-11 \mathrm{~cm}$ & $51-53 \mathrm{~cm}$ \\
\hline Quartz & 20.1 & 15.7 & 12.7 & 7.2 & 6.2 \\
Feldspar & 25.4 & 12.6 & 22.2 & 5.5 & 3.5 \\
Rock fragments & & & & & \\
$\quad$ Clastics & 8.8 & 10.7 & 5.3 & 31.6 & 44.7 \\
$\quad$ Chert & + & + & 0.6 & 11.2 & 12.2 \\
$\quad$ Limestone & - & + & - & 3.8 & 2.5 \\
$\quad$ Igneous & 14.9 & 12.7 & 33.7 & 27.3 & 17.0 \\
Heavy minerals & 3.5 & 0.5 & 0.5 & 0.3 & + \\
Matrix & 21.3 & 47.1 & - & 10.0 & 0.7 \\
Calcite cement & 6.0 & 0.7 & - & 3.1 & 13.2 \\
Silica cement & - & - & 25.0 & - & - \\
\hline
\end{tabular}

The diatom assemblages from a few selected samples of the nodules were examined by Dr. Itaru Koizumi. The results of his examination are given in Table 4 and are summarized as follows:

Sample $434-19-1,10-12 \mathrm{~cm}$ is characterized by an assemblage of the Denticula kamtschatica-D. seminae fossilis Zone (middle Pliocene), while the diatom assemblage of Sample 434-19,CC represents the upper part of the Denticula kamtschatica Zone (early Pliocene). Because Core 19 from Hole 434 is placed in the Denticula kamtschatica-D. seminae fossilis Zone (Harper, this volume), Sample 434-19-1, 10-12 cm is autochthonous in origin, and Sample 434-19,CC is allochthonous. Sample 434-27-1, $65 \mathrm{~cm}$ is also autochthonous, because samples from the Denticula kamtschatica Zone of Hole 434 cores include the diatom assemblage of the same zone.

Sample 434B-32,CC, $10-12 \mathrm{~cm}$ contains a diatom assemblage of the Denticula lauta Zone (middle Mio- cene). Since Core 434B-32 corresponds to the $D$. hustedtii Zone, the present sample is regarded as allochthonous.

\section{DISCUSSION}

Exotic pebbles occur in concentrations at particular levels from the Pleistocene to the Miocene in all the holes. Especially, the greatest amount of pebbles occurs in the Pliocene and Pleistocene (Figure 2). Most of the exotic pebbles from these sequences at Sites 434 and 435 are ascribable to intense ice-rafting, while some could have been introduced by down-slope slumping. Pebbles found at Site 436, even including those from the Miocene sequence, may have been rafted by ice, because they were found beyond the trench, which must have served as a barrier to supply by slumping from island arcs. However, it is not clear from paleontological data if pebbles from the Miocene sequence were deposited during an interval of cold climate.

Ice-rafted pebbles could have been derived from altered andesites, dacites, and associated volcaniclastic rocks, as well as sedimentary, metamorphic, and plutonic rocks in the Kurile-Kamchatka-Aleutian land areas, because cold currents responsible for distribution of rafted pebbles may have been basically unchanged from the present back at least to the Miocene. Conolly and Ewing (1970) came to a similar conclusion concerning the distribution of ice-rafted detritus in the Pleistocene of piston cores from the northwest Pacific.

Most of the dacite pebbles found at Sites 434 and 435 may be of the same age and composition as dacite conglomerates cored at Site 439 (von Huene, Nasu, et al., this volume). However, those found in Hole 436 cores cannot be related directly to the Site 439 dacite, because Site 436 was far seaward of the trench during deposition of the dacite pebbles.

TABLE 3

Chemical Compositions of Carbonate Nodules*

\begin{tabular}{|c|c|c|c|c|c|c|c|c|}
\hline \multirow[b]{3}{*}{ Component } & \multicolumn{8}{|c|}{ Analysis Number and Sample } \\
\hline & 1 & 2 & 3 & 4 & 5 & 6 & 7 & $8 * *$ \\
\hline & $\begin{array}{c}434-23-3 \\
49 \mathrm{~cm}\end{array}$ & $\begin{array}{c}434-27-1 \\
65 \mathrm{~cm}\end{array}$ & $\begin{array}{c}434-28-1, \\
104-106 \mathrm{~cm}\end{array}$ & $\begin{array}{c}434-29, \mathrm{CC}, \\
12-14 \mathrm{~cm}\end{array}$ & $\begin{array}{c}434 \mathrm{~B}-30-1, \\
5-10 \mathrm{~cm}\end{array}$ & $\begin{array}{c}434 \mathrm{~B}-32, \mathrm{CC} \\
12-14 \mathrm{~cm}\end{array}$ & $\begin{array}{c}435-9-1, \\
124-126 \mathrm{~cm}\end{array}$ & HT12' \\
\hline $\mathrm{SiO}_{2}$ & 19.02 & 22.74 & 34.22 & 32.37 & 31.04 & 8.97 & 32.25 & 20.84 \\
\hline $\mathrm{TiO}_{2}^{2}$ & 0.19 & 0.18 & 0.23 & 0.22 & 0.21 & 0.17 & 0.33 & 0.24 \\
\hline $\mathrm{Al}_{2} \mathrm{O}_{3}$ & 2.38 & 3.29 & 6.20 & 5.50 & 5.30 & 1.56 & 6.05 & 3.75 \\
\hline $\mathrm{Fe}_{2} \mathrm{O}_{3}$ & 1.11 & 1.06 & 1.06 & 1.05 & 1.05 & 2.61 & 1.31 & 2.52 \\
\hline $\mathrm{FeO}$ & 0.63 & 0.78 & 0.80 & 0.65 & 1.90 & 5.47 & 2.32 & 4.51 \\
\hline $\mathrm{MnO}$ & 0.56 & 0.36 & 0.13 & 0.15 & 7.43 & 17.42 & 0.16 & 0.32 \\
\hline $\mathrm{MgO}$ & 3.15 & 11.73 & 1.69 & 1.79 & 0.0 & 0.0 & 9.84 & 12.10 \\
\hline $\mathrm{CaO}$ & 1.01 & 4.18 & 3.87 & 2.42 & 2.94 & 16.35 & 4.93 & 8.64 \\
\hline $\mathrm{Na}_{2} \mathrm{O}$ & 0.0 & 0.47 & 0.68 & 0.60 & 6.26 & 2.07 & 1.05 & 0.25 \\
\hline $\mathrm{K}_{2} \mathrm{O}$ & 0.18 & 0.65 & 0.91 & 0.90 & 0.70 & 0.40 & 1.01 & 0.60 \\
\hline $\mathrm{P}_{2} \mathrm{O}_{5}$ & 0.50 & 0.39 & 0.37 & 0.37 & 1.36 & 7.75 & 0.18 & 0.32 \\
\hline $\mathrm{H}_{2} \mathrm{O}$ & 2.23 & 1.78 & 2.30 & 1.96 & 1.48 & 1.56 & 3.71 & 1.86 \\
\hline $\mathrm{CaCO}_{3}$ & 65.42 & 37.09 & 44.92 & 48.77 & 31.09 & 25.06 & 22.36 & 25.81 \\
\hline Other ${ }^{3}$ & 2.66 & 15.22 & 1.62 & 2.32 & 9.55 & 8.79 & 14.39 & 18.52 \\
\hline Total & 99.04 & 99.92 & 99.00 & 99.07 & 100.31 & 99.18 & 99.89 & 100.28 \\
\hline
\end{tabular}

*Analyzed by Ryuichi Sugisaki.

**For comparison, a sample of a diatomaceous carbonate nodule from the upper Miocene Tobetsu Formation at Atsuta, northwestern Hokkaido (Okada, 1977). 

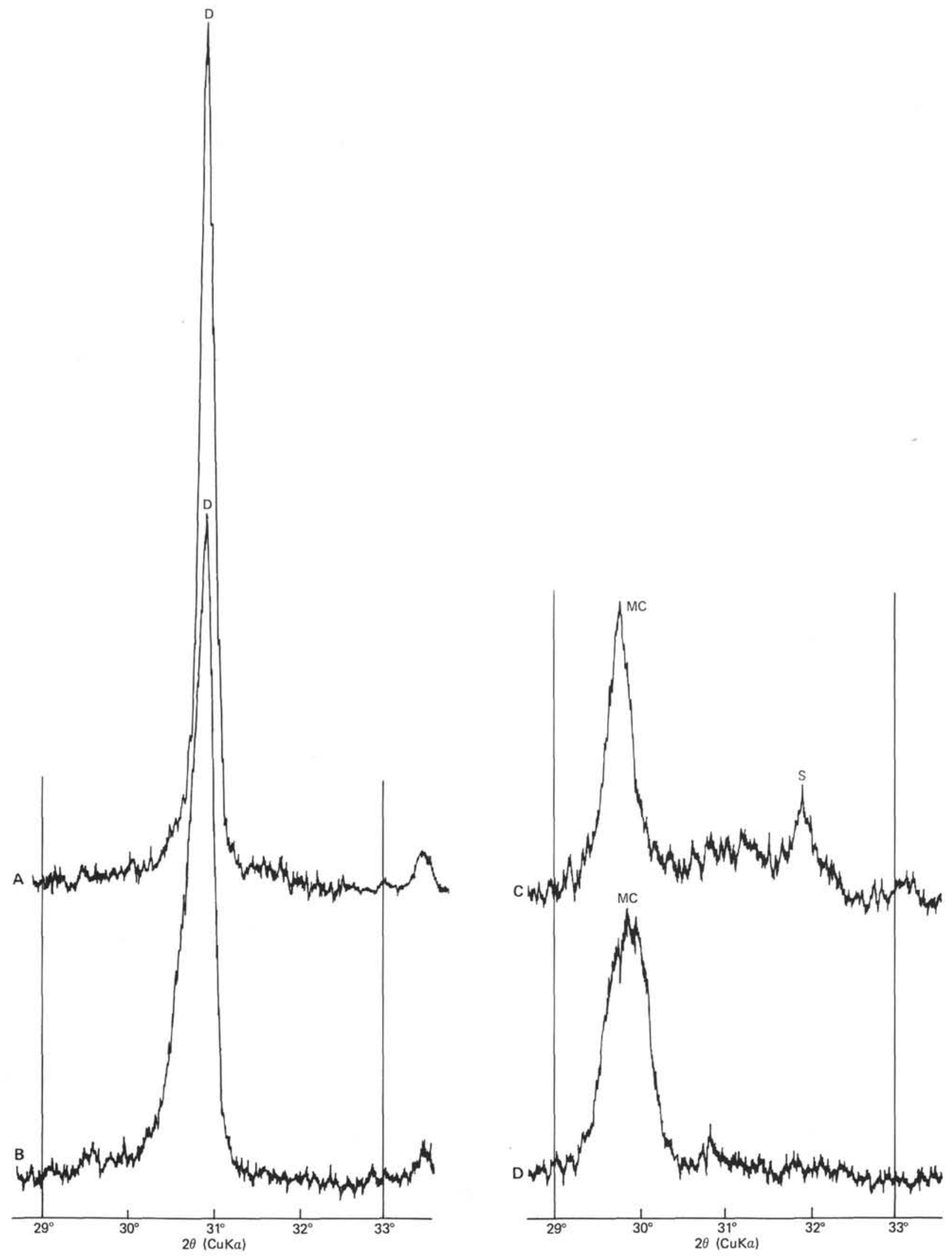

Figure 8. X-ray spectrogram indicating the (100) peaks of dolomite (D), manganoan calcite (MC), and siderite (S). A. Sample 435-9-1, 124-126 cm. B. Sample 434-27-1, $65 \mathrm{~cm}$. C. Sample 434B-32, CC, 12-14 cm. D. Sample 434B-30-1, 5-10 cm. 
TABLE 4

Diatom Species Observed in Carbonate Nodules from Site 434*

\begin{tabular}{|c|c|c|c|c|c|}
\hline \multirow[b]{2}{*}{ Taxa } & \multicolumn{5}{|c|}{ Samples } \\
\hline & $\begin{array}{c}434-19 \\
\text { CC }\end{array}$ & $\begin{array}{l}434-19-1 \\
10-12 \mathrm{~cm}\end{array}$ & $\begin{array}{c}434-27-1, \\
65 \mathrm{~cm}\end{array}$ & $\begin{array}{c}434 \mathrm{~B}-32, \mathrm{CC} \\
10-12 \mathrm{~cm}\end{array}$ & $\begin{array}{c}435-9-1 \\
124-126 \mathrm{~cm}\end{array}$ \\
\hline Actinocyclus curvatulus & & 2 & & & 4 \\
\hline A. divisus & & 1 & & & 1 \\
\hline A. ingens & & & & 6 & \\
\hline A. tsugarensis & & & & 3 & \\
\hline Bacteriosirs fragilis & & 1 & & & 1 \\
\hline Coscinodiscus curvatulus & & & 2 & & \\
\hline C. marginatus & 23 & 5 & 10 & 2 & 6 \\
\hline C. nodulifer & & 1 & & 1 & 1 \\
\hline C. oculus iridis & & & & & 1 \\
\hline C. postulatus & & & & & 2 \\
\hline Denticula kamtschatica & 38 & 4 & 63 & & 3 \\
\hline D. kanayae & & & & 6 & \\
\hline D. lauta & & & & 41 & \\
\hline D. seminae $\mathrm{v}$, fossilis & & 35 & 44 & & \\
\hline Eucampia sp. & & & & 2 & \\
\hline $\begin{array}{l}\text { Goniothium lemue } \\
\text { Hemidiscus cuneiformis }\end{array}$ & & & & 1 & 1 \\
\hline $\begin{array}{l}\text { Hemidiscus cuneiformis } \\
\text { Medialia splendida }\end{array}$ & & & & 1 & \\
\hline Nitzschia fossilis & & 1 & & & \\
\hline N. reinholdii & 2 & & & & 2 \\
\hline Pseudoposira elegans & & 12 & & & 2 \\
\hline Rhizosolenia barboi & & & & & 5 \\
\hline Rouxia naviculoides & & & & 3 & \\
\hline Stephanopyxis horridus & & & & & 2 \\
\hline S. inermis & 4 & 1 & & & \\
\hline S. turnis & & & 3 & & 3 \\
\hline Syndera californicus & & & & 6 & \\
\hline Thalassionema nitzschioides & 10 & 6 & 7 & 9 & 16 \\
\hline Thalassiosina antiqua & 11 & 9 & 4 & & 1 \\
\hline$T$. convexa & 2 & 1 & & & \\
\hline T. decipiens & & 1 & 1 & & 1 \\
\hline T. eccentrica & & 1 & & & \\
\hline T. gravida v, fossilis & & & 2 & & \\
\hline T. jacksonit & & & I & & \\
\hline T. leptopus & & 1 & & 1 & 2 \\
\hline T. nidulus & & 3 & 2 & & 3 \\
\hline T. nordenskioldii & & 4 & & & \\
\hline T. oestrupii & 1 & 1 & 2 & & \\
\hline T. pacifica & & 1 & & & \\
\hline T. plicatus & & & 2 & & \\
\hline T. zabelinae & 6 & 6 & 1 & & \\
\hline T. undulosa & & & & $\mathrm{t}$ & \\
\hline T. gravida v. fossilis & 2 & & & & \\
\hline Thalassiothrix longissima & 1 & 3 & & & \\
\hline $\begin{array}{l}\text { Triceratium condeconum } \\
\text { Thelassionema hirosakiensis }\end{array}$ & & & & $\begin{array}{r}1 \\
16\end{array}$ & \\
\hline Total tests & 100 & 100 & 100 & 100 & 100 \\
\hline Diatom zone** & D. . . & D.k.-D.s. & $D . k$. & D.. & D.k.-D.s. \\
\hline
\end{tabular}

"Data of 1. Koizumi.

$\because$ D.k. = Denticula kamtschatica Zone, D.k.-D.s. $=$ Denticula kamtschatica-D. seminae $\gamma$. fossilis Zone, D.I. = Denticula lauta Zone.

Carbonate nodules are abundant only in Site 434 cores. The nodules must have been much larger than cored pieces, and may have formed either lenses or beds. Some samples of carbonate nodules are transitional between marlstone and tuff (Plate 3, Figures 2, 3, $5,6,8)$. It is worthwhile to mention that petrographic and lithologic features of the nodules and their host diatomaceous sediments are analogous to those of nodules and their host rocks from upper Cenozoic sediments in northwestern Hokkaido (Table 3, analysis 8; Okada, 1977) and northern Honshu (Taguchi, 1961; Wantanabe, 1970).

The diatom assemblages from carbonate nodules suggest that some pieces of nodules are definitely autochthonous and some are allochthonous. Allochthonous pieces may have been derived by slumping.

Some samples clearly show that the matrix of vitric tuff is entirely replaced by microcrystalline carbonate minerals. Similar features are also very common in upper Cenozoic sediments in northwestern Hokkaido and northern Honshu (Okada, 1977; Watanabe, 1970; and others). The refractive index of glass shards from a piece of vitric tuff is nearly equivalent to that of glasses in the surrounding sediments in all the Leg 56 holes
(Furuta, this volume). All these glass shards indicate a rhyolitic composition.

These lines of evidence suggest that the carbonate nodules were diagenetically formed at or near the sites where they occur. Some chemical aspects of the nodules and their surrounding sediments should be taken into account. First, a high content of $\mathrm{P}_{2} \mathrm{O}_{5}$ in the nodules may reflect intervals very rich in organic matter. This is in accordance with enormous amounts of diatoms in the sediments which contain the nodules. Also, the value shown in Table 3 under the item "other" is also very high. This may mean a high content of organic matter. Second, all the cores down to 250 meters sub-bottom at Site 434 had a strong odor of $\mathrm{H}_{2} \mathrm{~S}$, which suggests an anaerobic environment. Whelan (this volume), in a study of organic geochemistry of Site 434 cores, points out that interstitial-water alkalinity is high in the sediments with a strong $\mathrm{H}_{2} \mathrm{~S}$ odor. She states that high alkalinity correlates well with activities of anaerobic organisms and is favorable to the formation of carbonate nodules.

Berner (1968), using experimental results, underlined the importance of anaerobic decomposition of organic matter for the genesis of carbonate nodules, pointing out that $\mathrm{NH}_{3}$ generated by decomposition of protein results in an increase in $\mathrm{pH}$ in microenvironments of sediments and encourages precipitation of carbonate. Hirabayashi (1977) also concludes in his geochemical study of carbonate concretions in the Joban coal field and Oga Peninsula in northern Honshu that the decomposition of organic substances in sediments is responsible for the formation of carbonate concretions.

It seems to me that anaerobic decomposition of organic matter in the sediments caused the formation of the carbonate nodules now in question. If the interpretation that the carbonate nodules in the trench sediments were formed diagenetically, in situ is correct, it will give an important clue to resolve problems of the genesis of carbonate nodules in ancient "geosynclinal" sediments. It is likewise important that these carbonate nodules definitely occur below the $\mathrm{CCD}$, as clearly shown by the absence of calcareous microfossils in the sediments cored at Site 434 (Thompson, this volume).

The marlstone breccias from Hole 434 suggest that the marlstones were subjected to intense tectonic brecciation together with the sediments in which they were embedded. This agrees well with severe deformation and fracturing of the sediments in Site 434 cores (Arthur et al., this volume).

\section{SUMMARY}

Exotic pebbles in these sediments usually are well rounded and consist of various rock types: dacite, andesite, basalt, vitric tuff, tuff breccia, gabbro, granodiorite, pumpellyite metaquartzite, biotite hornfels, fine-grained lithic wacke, and mudstone or slate. They are common particularly in the Pliocene-Pleistocene sequence, and are probably rafted by ice. This is especially true of pebbles from Site 436. Some pebbles at the other sites may have been slumped. 
Carbonate nodules are abundant only in Site 434 cores. They are mostly marlstone, and partly either calcareous tuff or micritic limestone. The marlstone, the limestone, and the matrix of the calcareous tuff show a microcrystalline texture and are composed of the minerals dolomite, manganoan calcite, and siderite. The chemical composition of the nodules indicates that the $\mathrm{CaCO}_{3}$ content is rather low, ranging 22 to 65 per cent, whereas the $\mathrm{P}_{2} \mathrm{O}_{5}$ content is commonly high.

The nodules are generally rich in diatom remains, and sometimes in glass shards. The diatom assemblages of some of the nodules are assigned to the same diatom zone established for the surrounding sediments. Volcanic glasses contained in the nodules also are almost identical in refractive index to those in the sediment in which the nodules are embedded. Therefore, these nodules mostly must have been formed in situ, diagenetically.

The formation of these nodules may be closely related to changes of $\mathrm{pH}$ in microenvironments of sediments owing to the decomposition of organic matter under anaerobic conditions, although further studies of the carbonate nodules are needed for a final conclusion concerning their origin. It is also important that these carbonate nodules occur clearly below the CCD. This case may clarify the genesis of the carbonate nodules commonly found in ancient "geosynclinal" sediments.

\section{ACKNOWLEDGMENTS}

I wish to thank Drs. Shoji Arai and Naoshi Kuroda (Shizuoka University) and Messrs. Kantaro Fujioka and Toshio Furuta (Ocean Research Institute, University of Tokyo) for their help in petrological and mineralogical examinations of pebbles; Dr. Itaru Koizumi (Osaka University) for his help in diatom examination; and Dr. Ryuichi Sugisaki (Nagoya University) for his help in chemical analysis of carbonate nodules. I am thankful to Drs. Kazuo Taguchi (Tohoku University) and Nobuaki Niitzuma (Shizuoka University) for critically reading the manuscript.

This study was supported by the Japanese Scientific Advisory Board for the International Phase of Ocean Drilling and a Grant-in-Aid for Scientific Researches from the Ministry of Education, Japan (Grant No. 246037).

\section{REFERENCES}

Berner, R. A., 1968. Calcium carbonate concentration formed by the decomposition of organic matter. Science, 159, 159-197.

Conolly, J. R., and Ewing, M., 1970. Ice-rafted detritus in northwest Pacific deep-sea sediments. Geol. Soc. Am. Mem., 126, 219-231.

Hirabayashi, K., 1977. Sedimentological and geochemical study on carbonate concretions in the Joban coal-field and Oga Peninsula, Northeast Japan. Sci. Repts. Tohoku Univ., Ser. 3, 13, 183-226.

Okada, H., 1977. Mineralogy, petrology, and sedimentary history. In Ujiie, H., Saito, T., et al., Biostratigraphy, Paleomagnetism and Sedimentology of Late Cenozoic Sediments in Northwestern Hokkaido: Japan. Bull. National Sci. Mus., Ser. C., 3, 69-77.

Taguchi, K., 1961. The introduction to the geochemical researches of the Onnagawa and the Funakawa petroliferous formations. J. Japan. Assoc. Petrol. Tech., 26, 278-288. [In Japanese with English abstract]

Watanabe, M., 1970. Carbonate concretions in the Neogene Tertiary System, Northeast Japan. Sci. Repts. Tohoku Univ., Ser. 3, 11, 69-112. 



\section{PLATE 1}

Photomicrographs of Exotic Pebbles

Figure 1 Intensely silicified augite-hypersthene dacite (Sample $435-7-1,19-20 \mathrm{~cm})$. Phenocryst plagioclase is altered to kaolinite and calcite; augite to epidote; and hypersthene to chlorite. The ground-mass is mainly composed of oligoclase microlites. Plane polarized light. Scale bar $0.3 \mathrm{~mm}$.

Figure 2 Hornblende-biotite-pyroxene dacite (Sample 436$31-1,1-3 \mathrm{~cm}$ ). Plane polarized light. Scale bar 0.3 $\mathrm{mm}$.

Figure 3 Hornblende-biotite-augite-hypersthene dacite (Sample $435-5-3,11-12 \mathrm{~cm}$ ). Plane polarized light. Scale bar $0.3 \mathrm{~mm}$.

Figure 4 Altered dacite (Sample 434-25-2, 86-90 cm). Phenocryst plagioclase is replaced by kaolinite; hornblende by magnetite and biotite along the margin. The groundmass is intensely silicified. Crossed nicols. Scale bar $0.3 \mathrm{~mm}$.

Figures 5, 6 Hypersthene-augite andesite (Sample 434-27-1, 65 $\mathrm{cm})$. Phenocryst plagioclase more or less replaced by kaolinite; pyroxene mostly altered to chlorite (Figure 6). Plane polarized light. Scale bar $0.3 \mathrm{~mm}$ for Figure 5, $0.1 \mathrm{~mm}$ for Figure 6.

Figures 7, 8 Hypersthene andesite (Sample 435-7-1, 43-44 cm). Phenocryst plagioclase is labradorite. Plane polarized light (Figure 7); crossed nicols (Figure 8). Scale bar $0.3 \mathrm{~mm}$. 
PLATE 1
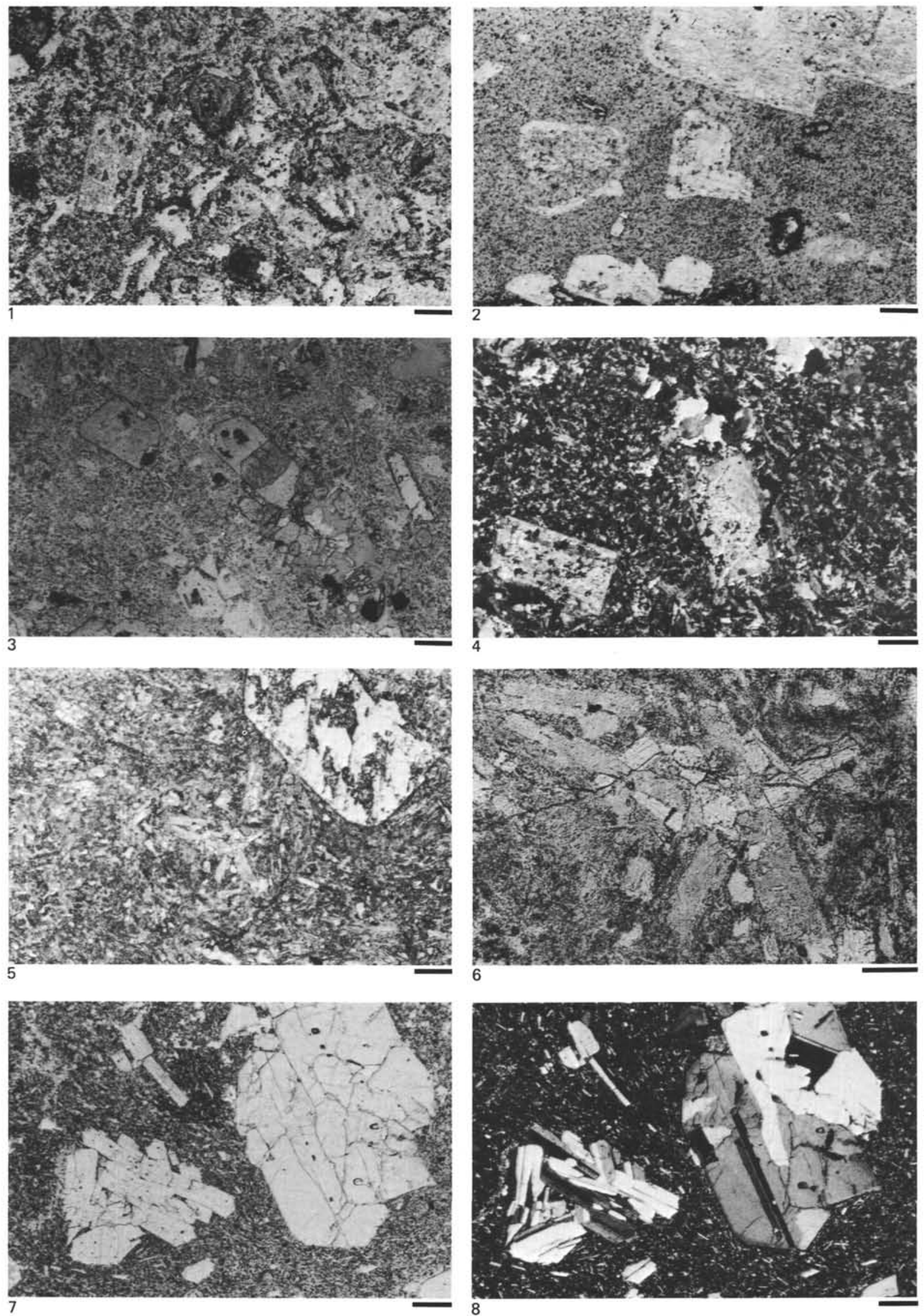


\section{PLATE 2}

Photomicrographs of Exotic Pebbles

(Scale bar $0.3 \mathrm{~mm}$ unless otherwise noted.)

Figure $1 \quad$ Volcanic breccia (Sample 434-25-2, 86-90 cm) composed of fragments of basalt, pumice, and dacite. Plane polarized light.

Figure 2 Granodiorite (Sample 435-14-1, 12-15 cm). Plane polarized light.

Figures 3, 4 Augite gabbro (Sample 434B-34-1, 6-8 cm) with ophitic texture. Plagioclase composition is $\mathrm{An}_{51}$. Plane polarized light (Figure 3); crossed nicols (Figure 4).

Figures 5, 6 Pumpellyite metaquartzite (Sample 435-14-1, 4-7 $\mathrm{cm})$. Yellow pumpellyite occurs as patches and fillings along sutures of mylonitized polycrystalline quartz and shows anomalous interference colors from bluish gray to yellowish gray. Quartz shows intense wavy extinction (Figure 6). Plane polarized light (Figure 5); crossed nicols (Figure 6).

Figure 7 Andesitic scoria (Sample 436-14-2, 29-30 cm). Plane polarized light. Scale bar $0.1 \mathrm{~mm}$.

Figure 8 Biotite hornfels (Sample 436-4-4, 60-66 cm) of fine-grained quartzose wacke origin. Plane polarized light. 
PLATE 2
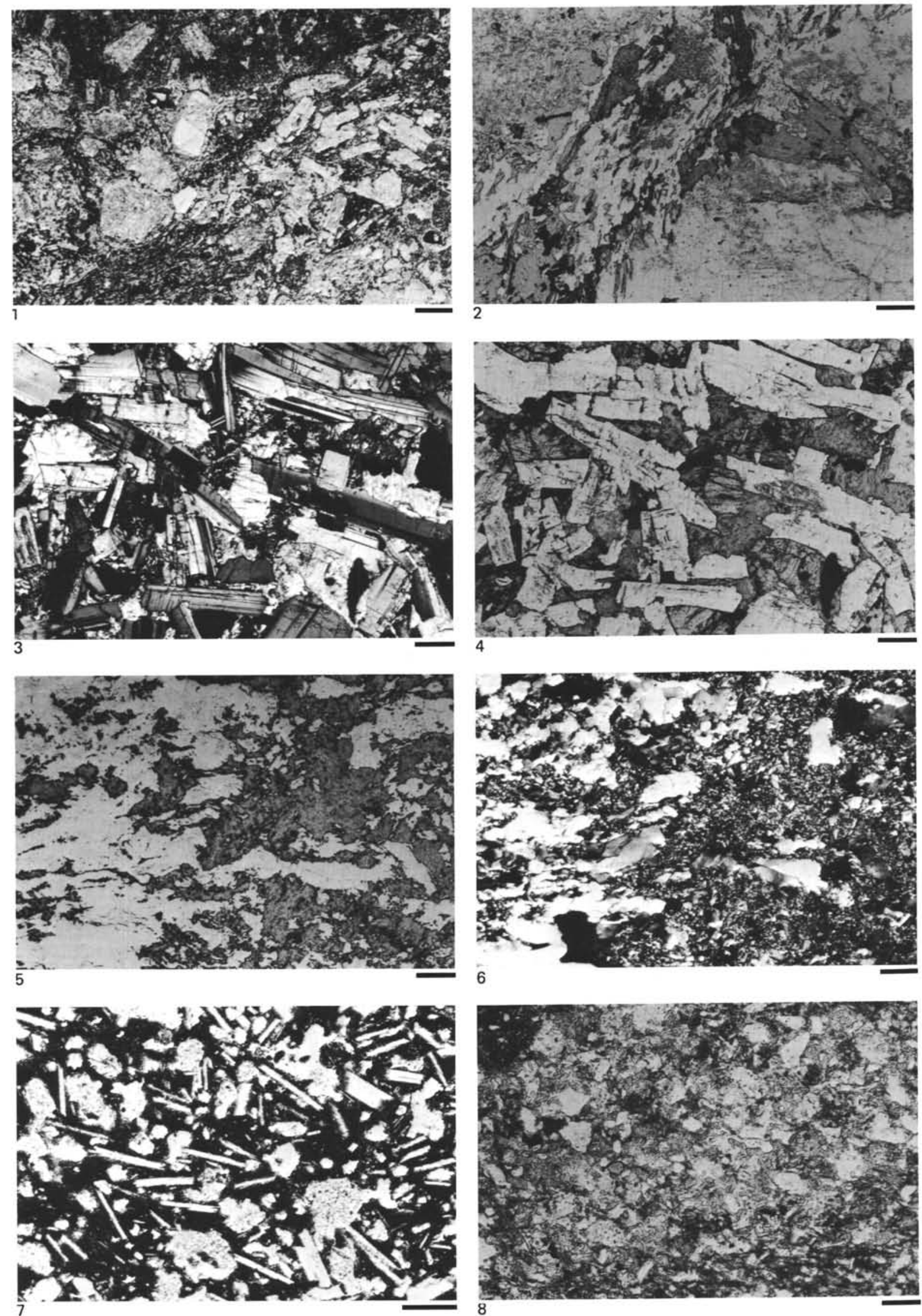
PLATE 3

Photomicrographs of Exotic Pebbles and Carbonate Nodules (Scale bar $0.1 \mathrm{~mm}$ unless otherwise noted.)

Figure 1 Poorly sorted, fine-grained lithic wacke (Sample 435-14-1, 12-15 cm). Plane polarized light.

Figure 2 Calcareous vitric tuff (Sample 434B-30-1, 5-10 $\mathrm{cm})$. Fresh glass shards of rhyolitic composition and small amounts of diatoms, augite, biotite, and plagioclase are cemented by micrite. Plane polarized light.

Figures 3, 4 Plagioclase and pyrite-bearing, diatom-rich marlstone (Sample 434-19-1, 10-12 cm). Scale bar 0.3 $\mathrm{mm}$ and crossed nicols for Figure 3 .

Figure 5 Diatom-rich marlstone (Sample 434B-32,CC, 12$14 \mathrm{~cm}$ ). Plane polarized light. Scale bar $0.3 \mathrm{~mm}$.

Figure 6 Diatom, plagioclase, augite, and pumice-bearing marlstone with common glass shards (Sample 434-28-1, 104-106 cm). Plane polarized light.

Figure 7 Sparite-cemented micritic breccia (Sample 43428,CC). Crossed nicols.

Figure $8 \quad$ Diatom and augite-bearing, sandy marlstone with rare plagioclase and common glass shards (Sample 434B-19-2, 33-35 cm). Plane polarized light. Scale bar $0.3 \mathrm{~mm}$. 
PLATE 3
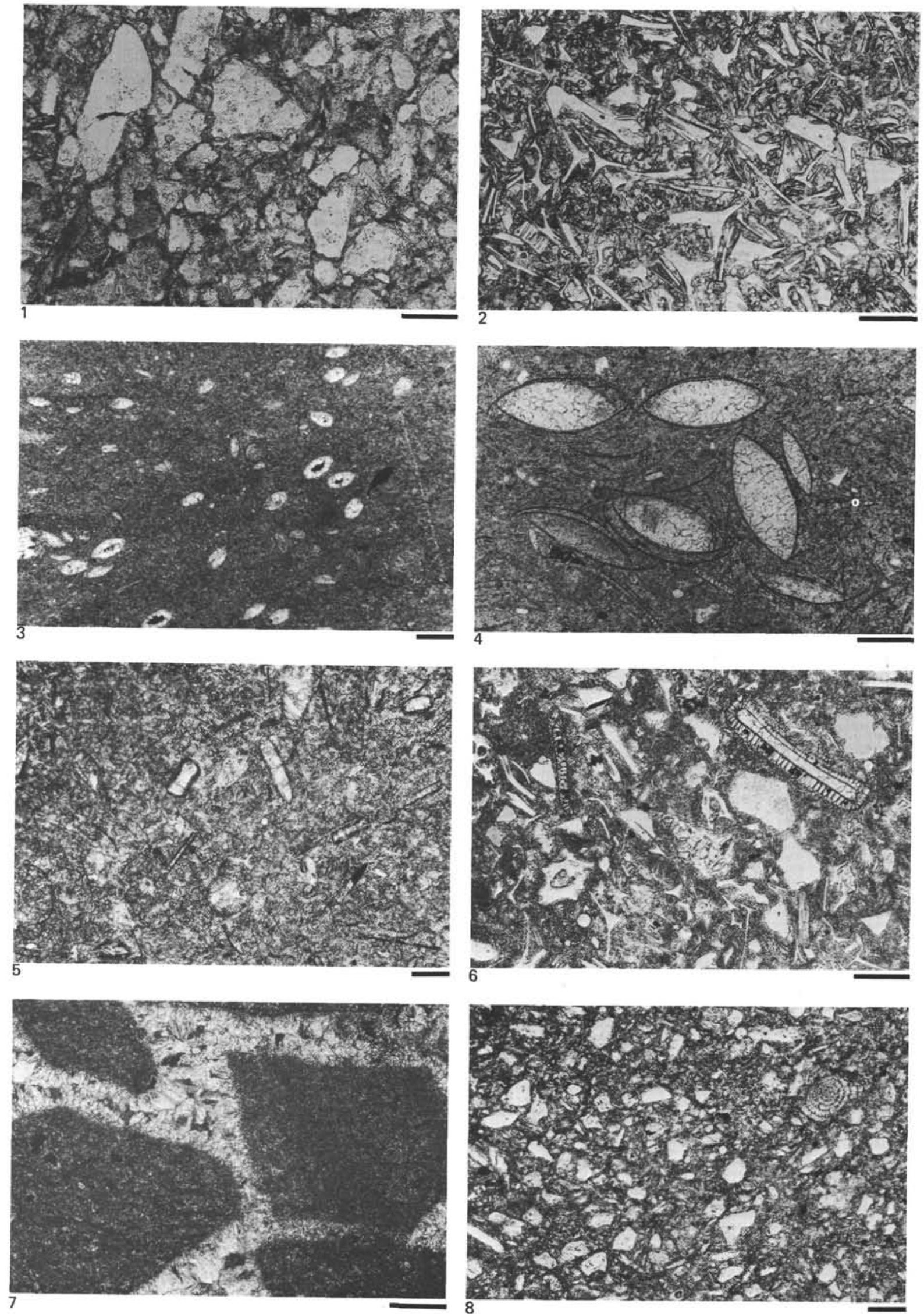